\title{
A simple and rapid protocol of crude DNA extraction from apple trees for PCR and real-time PCR detection of 'Candidatus Phytoplasma mali'
}

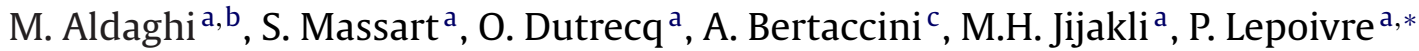 \\ a Plant Pathology Unit, Gembloux Agricultural University (FUSAGx), Passage des déportés 2, 5030 Gembloux, Belgium \\ ${ }^{b}$ Plant Diseases Department, Plant Pests E Diseases Research Institute (PPDRI), P.O. Box 19395-1454, Tehran, Iran \\ c Department of Agro-environmental Science and Technology, Plant Pathology, Alma Master Studiorum, University of Bologna, Bologna, Italy
}

\section{Article history:}

Received 17 June 2008

Received in revised form 1 October 2008

Accepted 7 October 2008

Available online 18 December 2008

\section{Keywords}

Phytoplasma

'Ca. P. mali'

Detection

Crude DNA extract

Purified DNA extract

\begin{abstract}
A B S T R A C T
Different PCR protocols have been established for detection of European fruit trees phytoplasmas; however the majority of the procedures for extracting phytoplasma DNA are complex, time consuming, and expensive, with a risk of contamination or loss of target DNA. In present study, a crude extract preparation method previously used to detect other plant pathogens was adapted to samples from apple trees infected by 'Candidatus Phytoplasma mali'. End-point and real-time PCR detection of 'Ca. P. mali' were used to compare this extraction procedure with an established method for efficient extraction of purified DNA. The crude extract proved fully adequate for phytoplasma detection in samples from 86 in vitro and 35 in vivo apple shoots or plants and 10 periwinkle plants. High inter- and intra-run reproducibility was obtained for phytoplasma detection with different TaqMan MGB- or SYBR Green-based real-time PCR protocols applied to the crude extracts. Real-time PCR applied to serially diluted crude and purified extracts revealed the same phytoplasma detection limit (dilution up to $10^{5}$ ). All results confirm the suitability of this simple, quick, efficient extraction technique for accurate detection of ' $\mathrm{C}$. P. mali' in different types of apple and periwinkle samples.
\end{abstract}

(c) 2008 Elsevier B.V. All rights reserved.

\section{Introduction}

Phytoplasmas are endocellular obligate parasitic phloemrestricted prokaryotes transmitted by sap-sucking insects and by vegetative plant propagation materials. These microorganisms are associated with more than 300 diseases in several hundred plant species worldwide (Marcone et al., 2004). Many phytoplasmas are on the list of quarantine organisms defined by EPPO (EPPO/CABI, 2006). The major phytoplasma identified in apple trees in European countries is 'Candidatus Phytoplasma mali', belonging to the "Apple Proliferation" group of phytoplasmas (Seemüller and Schneider, 2004).

In fruit nurseries, detection of phytoplasmas in plant tissues is a prerequisite to certification of plant materials. As fruit tree phytoplasmas usually occur at low titres and with uneven distribution in infected plants, their detection is difficult. In this context, the development of sensitive but also quick, reliable, and cost-effective methods for detecting fruit-tree phytoplasmas is essential to production of certified propagation materials (Bertaccini et al., 2004).

\footnotetext{
* Corresponding author. Tel.: +32 81 622433; fax: +32 81610126 .

E-mail address: lepoivre.p@fsagx.ac.be (P. Lepoivre).
}

The polymerase chain reaction (PCR) is the most versatile tool for detecting phytoplasmas in their hosts (Lee et al., 1993; Liu et al., 1994; Lorenz et al., 1995). Real-time PCR is preferred over endpoint PCR, which can be misleading because of enzyme instability and a decrease of reaction components over time (Ramakers et al., 2003).

PCR protocols usually require preparation of high-quality DNA (Heinrich et al., 2001) because of the possible presence of PCR inhibitors in phytoplasma-infected plant materials (Lepka et al., 1999; Musetti et al., 2000). Quality and quantity of phytoplasma DNA is strongly influenced by the extraction method and the species of plant or insect host (Marzachi and Bosco, 2005).

The response of molecular methods further depends strongly on the amount of phytoplasma cells or nucleic acids in the extract (Palmano, 2001). Given the typically very low titres of phytoplasmas, especially in woody hosts (Kartte and Seemüller, 1991; Lederer and Seemüller, 1991), and given their considerable variability according to the season and to the variety and the age of the infected plant (Berges et al., 2000; Seemüller et al., 1998), sensitive analysis requires efficient extraction of phytoplasma DNA of sufficient quality and in sufficient quantity.

Development of a rapid and efficient nucleic acid extraction procedure would allow testing many samples by PCR as it is necessary for example in epidemiological studies. A few such procedures have 
been reported (Levy et al., 1994; McGarvey and Kaper, 1991; Wang et al., 1993), but most DNA extraction techniques appear time consuming and costly (Boudon-Padieu et al., 2003; Palmano, 2001). To address these problems a quick, simple, and cheap new method yielding crude plant-tissue extracts suitable for the PCR-based detection of 'Ca. P. mali' in infected apple materials was developed in current study. The DNA extraction efficiency of this crude preparation method was further assessed by semi-quantitative evaluation of phytoplasma DNA using real-time PCR. The application of crude preparation of infected plants has been previously tested for virus detection by PCR amplification (Marinho et al., 1998; Marbot et al., 2002; Delanoy et al., 2003); furthermore a simple plant tissue preparation without homogenization suitable for detection of viruses by PCR was described by Thomson and Dietzgen (1995).

\section{Materials and methods}

\subsection{Phytoplasma and plant materials}

This work was carried out in samples from a collection of ' $\mathrm{Ca}$. P. mali' maintained in periwinkles under greenhouse conditions, and also from an established in vivo and in vitro collections of different 'Ca. P. mali' strains in apple rootstock MM106. These collections were prepared at summer 2005; in particular the in vivo MM106 apple tree collection was prepared on 4 years-old seedlings. Sampling for DNA extraction method testing was carried out in March, August, and October 2006 and 2007 from greenhousegrown plants. Extraction methods were tested on leaf tissues and tree-branch vascular (bark) tissue. For micro-propagated shoots, a pooled mix of all tissues was used.

\subsection{Preparation of crude DNA extracts}

The commercial extraction buffer KAJI (DNAlis sprl, Gembloux, Belgium) was used. To prevent rapid oxidation of plant materials during homogenization and clarification, ascorbic acid $(0.1 \%)$ was added to this extraction buffer. After homogenization of the plant material ( $200 \mathrm{mg}$ leaves or bark tissues collected and pooled from minimum 4 different branches) in $2 \mathrm{ml}$ cold extraction buffer by grinding with a Homex (Bioreba, Reinach, Switzerland) in disposable nylon mesh bags (Bioreba, Reinach, Switzerland), the suspension was clarified by centrifugation $(12,000 \times \mathrm{g}, 5 \mathrm{~min}$ at $4{ }^{\circ} \mathrm{C}$ ). The clarified extracts were diluted 10 times with sterile distilled water and either immediately placed on ice and used for detection or stored at $-20^{\circ} \mathrm{C}$.

\subsection{Purified DNA extraction}

The method used for extraction of purified DNA from phytoplasma-infected plants has been previously published (Aldaghi et al., 2007). Briefly, after homogenizing $200 \mathrm{mg}$ plant materials (leaves or bark tissue) in a mortar with CTAB buffer containing $0.2 \%$ 2-mercaptoethanol, the samples were incubated at $60^{\circ} \mathrm{C}$ for $30 \mathrm{~min}$. Following clarification with an equal volume of chloroform/isoamyl alcohol (24:1), vortexing, and centrifugation at $16,100 \times \mathrm{g}$ for $5 \mathrm{~min}$ at $4{ }^{\circ} \mathrm{C}$, the supernatant was transferred to a clean tube and nucleic acid was precipitated by adding an equal volume of ice-cold isopropanol. The mix was centrifuged $(16,100 \times g$ for $8 \mathrm{~min}$ at $4{ }^{\circ} \mathrm{C}$ ). The pellet was rinsed with $70 \%$ ethanol, dried, and finally resuspended in $1 \mathrm{ml}$ distilled water [normally the pellet is suspended in $100 \mu \mathrm{l}$ distilled water, but in this study it was suspended in $1 \mathrm{ml}$ (as 10 times diluted like crude extraction preparations)].

\subsection{Phytoplasma detection by end-point and real-time PCR}

Specific primers AP5/AP4 designed by Jarausch et al. (1994) were used to check crude extract preparations as template for phytoplasma detection by end-point PCR in comparison with templates from purified DNA extraction. Amplification reactions were performed by means of HotGoldStar PCR kit (Eurogentec, Seraing, Belgium) in PTC-200 PCR-System (MJ Research, USA). In each run, negative controls [healthy samples and template-free controls (sterile, distilled water)] were also used. End-point detection was carried out by electrophoresis of the PCR products through 1.5-2\% agarose gels, staining with ethidium bromide, and photographing the bands under UV illumination.

Three established real-time PCR protocols, a TaqMan MGB method (protocol 1) (Aldaghi et al., 2007, 2008) and two SYBR green methods (protocol 2 and 3) (respectively, Jarausch et al., 2004; Torres et al., 2005), were also used for phytoplasma detection from both DNA extract preparation methods. Reactions were performed in a total volume of $25 \mu \mathrm{l}$ containing $1 \times$ qPCR MasterMix for TaqMan or SYBR Green from Eurogentec (respectively for protocols 1 and 2), or Power SYBR Green ${ }^{\circledR}$ PCR MasterMix from Applied Biosystems, Warrington, UK (for protocol 3), $400 \mathrm{nM}$ of each primer (used in original protocols), $200 \mathrm{nM}$ TaqMan MGB probe (if applicable), and $5 \mu \mathrm{l}$ purified or crude DNA extract. Amplification and detection were performed with the GeneAmp 5700 Sequence Detection System (PE Applied Biosystems, Foster City, USA). Forty-five amplification cycles were carried out in all real-time PCR protocols. For each protocol, the denaturation, annealing, and elongation temperatures of the PCR were those proposed by the authors of the protocols. Each experiment included at least two healthy and two template-free negative controls (sterile, distilled water). Threshold lines were set so as to intersect the amplification curves in the linear region of the semilog plot. Threshold cycles $\left(C_{t}\right)$ for each PCR reaction were calculated with GeneAmp 5700 SDS software. The inter- and intra-run reproducibility of phytoplasma detection by each real-time PCR on crude extract was tested by carrying out two distinct runs for each reaction, with samples in triplicate. Statistical analyses were performed by the SAS Version 9.1 software (SAS Institute Inc., Cary, NC, USA). Statistical significance was tested at the $P<0.05$ level.

\subsection{Template detection limits of the two extraction methods}

The phytoplasma DNA detection limits of the two extraction methods were compared by serial dilution $\left(10-10^{6}\right)$ of extracts and real-time PCR using the TaqMan MGB probe (protocol 1). Purified and crude extracts of October samples were serially diluted. Five microlitres of each dilution and 45 cycles of amplification were used for the PCR. Mix reagents and other PCR conditions were as mentioned above. Each dilution was amplified in triplicate in the same run. The experiment was performed twice independently. Threshold levels were calculated according to the $10 \times$ standard deviation (S.D.) of the fluorescence values during 5-15th cycle, and adjusted to within $0.05-0.1$ (Dorak, 2006). The $C_{\mathrm{t}}$ values obtained with serially diluted extracts were used to determine the dilution limit for detection after extraction by each method.

\section{Results}

\subsection{Phytoplasma detection in crude DNA extracts by end-point $P C R$}

To test the efficiency and reliability of the crude extraction method, all experiments were performed with crude and purified 


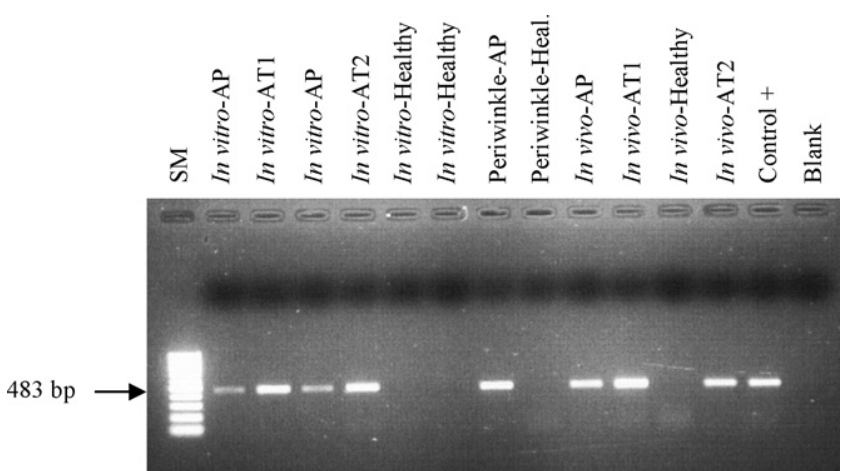

Fig. 1. PCR product analysis in agarose gel. PCRs, carried out to detect phytoplasma infection in different types of samples (in vitro and in vivo) after crude extraction, were performed with the AP5/AP4 primers. Samples were infected by three different strains of 'Ca. P. mali' (AP, AT1, and AT2). The in vivo and in vitro samples were, respectively, MM106 apple rootstocks and shoots cultured from them. Purified DNA extract of ' $\mathrm{Ca}$. P. mali' strain AP15 from periwinkle was used as positive control. The presence of a single band in all crude-extract samples shows the efficiency and reliability of this new extraction method (compared to purified DNA extraction) for phytoplasma detection by end-point PCR.

DNA extracts (prepared from the same plant samples) in parallel. Both methods yielded the same percentage of positive samples (34 samples were tested), and the results obtained with crude extracts were fully reproducible for phytoplasma detection (data not shown). For a given sampling period, two extraction techniques were completely concordant (no significant difference between crude and purified DNA extracts) for phytoplasma detection in endpoint PCR (data not shown). In general, the most reliable results for phytoplasma detection by both extraction techniques were obtained using vascular tissues versus leaf tissues, particularly for the apple greenhouse samples collected in March; moreover the number of positive among tested samples was increased according to the sampling period from March to October using both extraction techniques. Gel electrophoresis and ethidium bromide staining of the PCR products obtained from crude extracts revealed a single band of the expected size for all ' $\mathrm{Ca}$. P. mali' strains (Fig. 1). The crude extraction technique allowed PCR-based detection of phytoplasma infection in infected in vitro samples and in samples from inoculated apple and periwinkle plants maintained in a greenhouse (similar results were obtained with purified extracts). Furthermore, crude extracts were proved to be adequate for detecting the infection not only in plants exhibiting symptoms of different types and severities, but also in samples obtained from non-symptomatic parts of infected trees. No positive signal was observed for healthy and negative controls (Fig. 1).

\subsection{Phytoplasma detection in crude extract by real-time PCR protocols}

The results of phytoplasma detection by TaqMan MGB-based real-time PCR performed on crude and purified DNA extracts

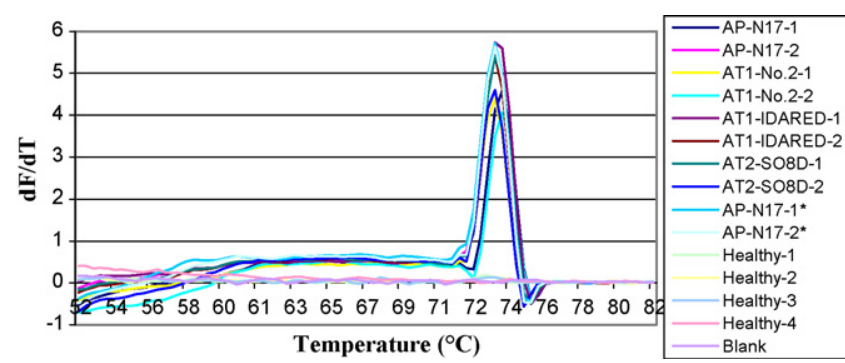

Fig. 2. Derivative melting curve analysis of 10 different phytoplasma-infected samples and four healthy samples obtained by protocol 2. For each infected sample a single peak in its melting curve is obvious (showing a unique PCR product). The samples marked by “*” are purified DNA extracts and the rest are crude extracts.

showed $100 \%$ agreement between the two methods (Table 1 ). Crude extraction allowed detection of phytoplasma infection in extracts from 76 out of 86 in vitro apple shoots, 29 out of 35 greenhousegrown apple plants, and 6 out of 10 greenhouse-grown periwinkle plants. Similar results were also obtained by purified extracts (Table 1). Real-time PCR performed with crude and purified extracts also revealed full intra- and inter-run reproducibility for phytoplasma detection. The inter-run reproducibility of PCR assays was evaluated by comparing the results obtained from separate runs. No statistical significant difference was observed between separate runs (data not shown). Furthermore, the coefficient of variation (CV) of the triplicates from each sample in the same run was always lower than $1.1 \%$.

Almost 18 crude extracts representative of the various sampling conditions (leaves or bark, in vitro or in vivo, apple or periwinkle infected by different phytoplasma strains) were tested by the three different real-time PCR protocols described above for ' $\mathrm{Ca}$. P. mali' detection. For each crude DNA sample, the results obtained were similar whatever the protocol used. The data (Table 2) show that the crude DNA extraction method can provide phytoplasma preparations suitable for detection by different real-time PCR protocols, only protocol 3 detected phytoplasma infection later (higher $C_{\mathrm{t}}$ values) than two other protocols for the same samples. The small S.D. values demonstrate the intra-run reproducibility of all three real-time protocols after crude extraction (Table 2 ). High inter-run reproducibility was also recorded for two runs of each real-time PCR protocol (data not shown). Derivative melting curves obtained after the SYBR Green-based PCR protocols applied to the various crude extracts showed a single melting peak, indicative of a single PCR product, at about $73^{\circ} \mathrm{C}$ (protocol 2 ) or $82^{\circ} \mathrm{C}$ (protocol 3) (Fig. 2).

\subsection{Comparison of template detection limit between two extraction methods}

Both DNA extraction methods were performed in parallel on the same samples (leaf and vascular tissue). Serially diluted extracts were analysed for the presence of the template to be detected by TaqMan MGB real-time PCR (Aldaghi et al., 2007, 2008). The results of these experiments are summarized in Table 3 . The $C_{t}$

Table 1

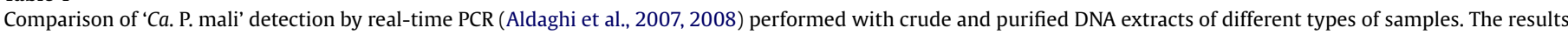
of the two methods are in complete agreement.

\begin{tabular}{|c|c|c|c|}
\hline Method & In vitro apple samples ${ }^{\mathrm{a}}$ & Greenhouse apple samples ${ }^{\mathrm{a}}$ & Greenhouse periwinkle samples ${ }^{\mathrm{a}}$ \\
\hline Crude DNA extraction & $76 / 86$ & $29 / 35$ & $6 / 10$ \\
\hline Purified DNA extraction & $38 / 48^{\mathrm{b}}$ & $29 / 35$ & $6 / 10$ \\
\hline
\end{tabular}

\footnotetext{
a Positive sample number per total tested samples.

b Purified DNA extraction was not performed on all in vitro samples. Experiments were carried out in parallel on crude and purified extracts from 40 samples but

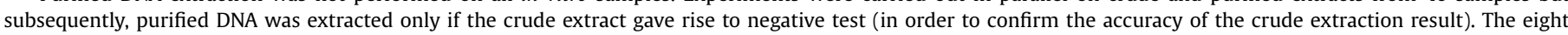
samples testing negative after crude extraction were also negative after purified DNA extraction.
} 
Table 2

Performance of phytoplasma detection in crude extracts of two samples by three different real-time PCR protocols.

\begin{tabular}{|c|c|c|c|c|c|c|}
\hline \multirow[t]{2}{*}{ Sample } & \multicolumn{2}{|c|}{$\begin{array}{l}\text { Real-time PCR protocol } 1 \\
\text { (Aldaghi et al., 2007) }\end{array}$} & \multicolumn{2}{|c|}{$\begin{array}{l}\text { Real-time PCR protocol } 2 \\
\text { (Jarausch et al., 2004) }\end{array}$} & \multicolumn{2}{|c|}{$\begin{array}{l}\text { Real-time PCR protocol } 3 \\
\text { (Torres et al., 2005) }\end{array}$} \\
\hline & $C_{\mathrm{t}}$ & S.D. & $C_{\mathrm{t}}$ & S.D. & $C_{\mathrm{t}}$ & S.D. \\
\hline AP-N17 & 24.43 & 0.01 & 24.15 & 0.38 & 28.30 & 0.45 \\
\hline AT1-IDARED & 23.39 & 0.38 & 24.19 & 0.35 & 29.25 & 0.17 \\
\hline
\end{tabular}

$C_{\mathrm{t}}=$ threshold cycle; each $C_{\mathrm{t}}$ value is a mean of three values. S.D. = standard deviation.

Table 3

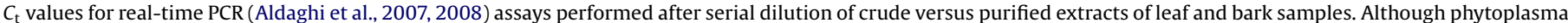
was detected sooner by purified extracts for dilutions 10 and $10^{2}$, detection limit of both extraction techniques for phytoplasma infection was similar (up to dilution $10^{5}$ ).

\begin{tabular}{|c|c|c|c|c|c|c|}
\hline \multirow[t]{2}{*}{ Method } & \multicolumn{6}{|c|}{ Mean $C_{\mathrm{t}}^{\mathrm{a}}$} \\
\hline & $\times 10$ & $\times 10^{2}$ & $\times 10^{3}$ & $\times 10^{4}$ & $\times 10^{5}$ & $\times 10^{6}$ \\
\hline \multicolumn{7}{|l|}{ Leaves } \\
\hline Crude DNA extract & V & 23.77 & 26.20 & 30.23 & 35.07 & ND \\
\hline Purified DNA extract & 18.29 & 22.52 & 26.46 & 30.32 & 34.87 & ND \\
\hline \multicolumn{7}{|l|}{ Bark } \\
\hline Crude DNA extract & V & 23.81 & 26.42 & 30.18 & 34.45 & ND \\
\hline Purified DNA extract & 18.46 & 22.57 & 26.52 & 30.52 & 34.09 & ND \\
\hline
\end{tabular}

$\mathrm{V}$ : these samples had variable $C_{\mathrm{t}}$ ranging 20-22. ND: not detected.

a Each reaction was performed twice.

values obtained with dilution $10 \times$ and to some extent with $100 \times$ were significantly lower for purified than for crude extracts, perhaps because of the presence of inhibitors at higher concentration of crude extracts. Nevertheless, both methods showed the same detection limit $\left(10^{5}\right)$ upon serial dilution (Table 3 ) and a similar $C_{t}$ value in the 34-35 cycles range at dilution $\times 10^{5}$ for both leaf and vascular tissues. In a few cases, the $C_{t}$ value was lower after crude extraction than after DNA purification (data not shown). The data presented in Table 3 also show that for a given sampling period, crude extraction from leaves or vascular tissues yielded similar results in the detection assay. This supports the reliability of the extraction technique in the case of sampling from different types of phloem tissue.

\section{Discussion}

The current study presents a rapid and simple procedure for phytoplasma DNA extraction that is suitable for ' $\mathrm{Ca}$. P. mali' detection by both end-point and real-time PCR assays. In terms of reliability and dilution limit, furthermore, the results obtained with this new method are in agreement with those reported for established phytoplasma detection methods known to yield high-quality DNA in sufficient quantity for phytoplasma detection.

Nucleic acid extraction from plant tissues is the most laborious and time-consuming step in detection, especially when handling a large number of samples. Many previously published nucleic acid extraction procedures for phytoplasma detection can lead to cross-contamination of samples and require expensive commercial materials or kits and at least a day of work for a few samples. In addition, it is sometimes difficult to extract relatively pure nucleic acids from some plants (Nakahara et al., 1999). For example, some plants are rich in phenolic compounds and polysaccharides, known to inhibit enzyme catalysis in PCR assays (Pandey et al., 1996; Staub et al., 1995).

Palmano (2001) has evaluated several DNA extraction methods in terms of the speed of analysis, the number of samples that can be simultaneously processed by a single operator, and operator safety. The results show that some commercial kits offering simplicity and speed are less sensitive than others for phytoplasma detection. To devise a reference procedure for detection of grapevine phytoplasmas, Boudon-Padieu et al. (2003) examined three extrac- tion methods and four PCR detection procedures. Although the PCR detection procedure proved more critical than the extraction method in the case of periwinkle samples, a quicker and less expensive DNA extraction method was selected for routine detection in grapevine samples. In another study, two extraction methods involving the use of chloroform/phenol and silica gel were compared for detection of European stone fruit phytoplasma in in vitro samples (Bertaccini et al., 2004): phytoplasmas were detected in some samples after silica gel extraction, while the other method yielded negative results.

Beforehand, simple or/and rapid protocols for tissue crude preparation or nucleic acid extraction without tissue homogenization were used for detection of viruses and viroids. Using crude preparation of tissues, apple stem grooving virus, potato virus $\mathrm{Y}$ and banana streak virus were detected by RT-PCR or real-time PCR (Marinho et al., 1998; Chandelier et al., 2001; Delanoy et al., 2003). Besides, simple and rapid methods for nucleic acid liberation towards suitable and sensitive detection of some viruses and viroids by PCR have been described by Thomson and Dietzgen (1995) and Nakahara et al. (1999), respectively.

In the present study, an extraction buffer newly developed by the Plant Pathology Department of the Gembloux Agriculture University and used previously for detection of plant viruses (Busogoro et al., 2008; Massart et al., 2008) was tested for ' $\mathrm{Ca}$. P. mali' detection. This buffer has been commercialized by a Belgian company (DNAlis sprl, Gembloux, Belgium) as a product for total nucleic extraction from a wide range of species. Using this buffer and the method presented for preparation of crude DNA extracts, the number of samples that can be processed simultaneously daily by a single operator being at least three times higher than with other techniques previously published. The crude extraction method makes it possible for a single operator to process 25-40 samples per day, as opposed to the 5-10 samples that can be processed daily by one person using the other technique used in the present paper (this result in reduced labour costs with this new extraction method). Moreover, the new protocol saves money by reducing the use of disposal materials including tips and tubes. On the other hand, most extraction procedures require concentrating nucleic acid in a small volume of liquid and eliminating inhibitors. The crude extraction method presented in this work is convenient for pathogen detection without DNA 
concentration or inhibitor elimination and suitable for PCR-based phytoplasma detection in samples collected at different seasons and from both leaves and vascular tissues. The results of the present work are in agreement with reported data for other fruit trees phytoplasmas showing the higher rate of detection in autumn (October) or winter compared to spring (March) and summer (August) (Jarausch et al., 1999; Errea et al., 2002; Garcia-Chapa et al., 2003).

A considerable amount of DNA is usually lost during different steps of DNA purification and concentration present in all methods previously published for phytoplasma-infected plants. The present crude extraction procedure involves only one step: tissue homogenization, so the risk of DNA loss is minimal. This is probably why the crude extracts using a pooled sampling from all parts of canopy to overcome the uneven distribution of the pathogen, resulted to be very effective in phytoplasma detection as compared to extraction methods involving purification. The minimal risk of DNA loss with this new technique enables us to detect phytoplasma in lowtitre hosts. In comparison to other methods previously published for phytoplasma DNA extraction, the new presented method minimises risks linked to the use of dangerous reagents that might affect operator safety, since KAJI buffer is free of toxic reagents like chloroform, phenol, and mercaptoethanol used in most DNA extraction methods for phytoplasma detection. In addition, this simple extraction protocol can be successfully performed without adding ascorbic acid to the buffer, in the case of tissues containing low levels of phenolic or other oxidizing compounds (unpublished data).

The new procedure appears reliable, with high accuracy for ' $\mathrm{Ca}$. P. mali' detection in both in vitro and in vivo plant samples by three different real-time PCR protocols (Jarausch et al., 2004; Torres et al., 2005; Aldaghi et al., 2007) and with high inter- and intrarun reproducibility. For detection of phytoplasma, the two SYBR Green real-time PCR protocols (protocols 2 and 3 ) used in present study yielded different $C_{\mathrm{t}}$ values possibly due to different levels of primer specificity and/or to the different master mixes used (protocol 3 was not applicable with the master mix used in protocol 2).

Both extraction methods compared in this study showed the same detection limit, although purified extracts showed a lower $C_{\mathrm{t}}$ value at low dilutions. This most likely reflects the presence of PCR inhibitors in the crude extracts. The importance of PCR inhibitors reduction in DNA extracts by means of dilution has been reported by many scientists (Boudon-Padieu et al., 2003; Ramakers et al., 2003; Albrechtsen, 2006). It should be stressed that this inhibitory effect reduced or disappeared at higher dilutions ( $100 \times$ and more) in the present work.

The simplicity, rapidity, and low cost of the new extraction method, combined with efficient and sensitive phytoplasma detection, make it useful for routine work. Further research will focus on evaluating its applicability to other phytoplasmas infecting different plant and insect species. As the DNAlis Company has commercialized this extraction buffer with a simplified sampling system (named PhytoPASS, Busogoro et al., 2008), efforts will also be devoted to testing the reliability of this crude extraction method for phytoplasma detection when this simplified sampling system is used.

\section{References}

Albrechtsen, S.E., 2006. Testing Methods for Seed-transmitted Viruses: Principles and Protocols. CABI Publishing, Wallingford, UK, $263 \mathrm{pp}$.

Aldaghi, M., Massart, S., Roussel, S., Dutrecq, O., Jijakli, M.H., 2008. Adaptation of real-time PCR assay for specific detection of apple proliferation phytoplasma. Acta Hort. 781, 387-393.
Aldaghi, M., Massart, S., Roussel, S., Jijakli, M.H., 2007. Development of a new probe for specific and sensitive detection of 'Candidatus phytoplasma mali' in inoculated apple trees. Ann. Appl. Biol. 151, 251-258.

Berges, R., Rott, M., Seemüller, E., 2000. Range of phytoplasma concentration in various plant hosts as determined by competitive polymerase chain reaction. Phytopathology 90, 1145-1152.

Bertaccini, A., Paltrinieri, S., Caprara, L., Laimer, M., Hanzer, V., Balla, I., 2004 Improved molecular methods for detection of European stone fruit yellows (ESFY) phytoplasmas from in vitro shoots of fruit trees. Acta Hort. 657, 495-500.

Boudon-Padieu, E., Bejat, A., Clair, D., Larrue, J., Borgo, M., Bertotto, L., Angelini, E. 2003. Grapevine yellows: comparison of different procedures for DNA extraction and amplification with PCR for routine diagnosis of phytoplasmas in grapevine. Vitis 42, 141-149.

Busogoro, J.P., Masquelier, L., Kummert, J., Dutrecq, O., Lepoivre, P., Jijakli, M.H., 2008 Application of a simplified molecular protocol to reveal mixed infections with Begomoviruses in Cassava. J. Phytopathol. 156, 452-457.

Chandelier, A., Dubois, N., Baelen, F., De Leener, F., Warnon, S., Remacle, J., Lepoivre, P., 2001. RT-PCR-ELOSA tests on pooled sample units for the detection of virus $Y$ in potato tubers. J. Virol. Methods 91, 99-108.

Delanoy, M., Salmon, M., Kummert, J., Frison, E., Lepoivre, P., 2003. Development of real-time PCR for the rapid detection of episomal banana streak virus (BSV). Plant Dis. 87, 33-38.

Dorak, M.T., 2006. Real-time PCR. Accessed June 2008 at http://dorakmt tripod.com/genetics/realtime.html.

EPPO/CABI, 2006. Apple proliferation phytoplasma. In: Smith, I.M., McNamara, D.G. Scott, P.R., Harris, K.M. (Eds.), Quarantine Pests for Europe, 2nd edn. CAB International, Wallingford, UK, pp. 959-962.

Errea, P., Aguelo, V., Hormaza, J.I., 2002. Seasonal variations in detection and transmission of pear decline phytoplasma. J. Phytopathol. 150, 439-443.

Garcia-Chapa, M., Medina, V., Viruel, M.A., Lavina, A., Battle, A., 2003. Seasonal detection of pear decline phytoplasma by nested-PCR in different pear cultivars. Plant Pathol. 52, 513-520.

Heinrich, M., Botti, S., Caprara, L., Arthofer, W., Strommer, S., Hanzer, V., Katinger H., Bertaccini, A., Laimer, M., 2001. Improved detection methods for fruit tree phytoplasmas. Plant Mol. Biol. Rep. 19, 169-179.

Jarausch, W., Lansac, M., Dosba, F., 1999. Seasonal colonization pattern of European stone fruit yellows phytoplasma in different Prunus species detected by specific PCR. J. Phytopathol. 147, 47-54.

Jarausch, W., Peccerella, T., Schwind, N., Jarausch, B., Krczal, G., 2004. Establishment of a quantitative real-time PCR assay for the quantification of apple proliferation phytoplasmas in plants and insects. Acta Hort. 657, 415-420.

Jarausch, W., Saillard, C., Dosba, F., Bove, J.M., 1994. Differentiation of mycoplasmalike organisms (MLOs) in European fruit trees by PCR using specific primers derived from the sequence of a chromosomal fragment of the apple proliferation MLO. Appl. Environ. Microbiol. 60, 2916-2923.

Kartte, S., Seemüller, E., 1991. Susceptibility of grafted Malus taxa and hybrids to apple proliferation disease. J. Phytopathol. 131, 137-148.

Lederer, S., Seemüller, E., 1991. Occurrence of mycoplasma-like organisms in diseased and non-symptomatic alder trees (Alnus spp.). Eur. J. Forest Pathol. 21, 90-96.

Lee, I.M., Hammond, R.W., Davis, R.E., Gundersen, D.E., 1993. Universal amplification and analysis of pathogen 16S rDNA for classification and identification of mycoplasmalike organisms. Phytopathology 83, 834-842.

Lepka, P., Stitt, M., Moll, E., Seemüller, E., 1999. Effect of phytoplasmal infection on concentration and translocation of carbohydrates and amino acids in periwinkle and tobacco. Physiol. Mol. Plant Pathol. 55, 59-68.

Levy, L., Lee, I., Hadidi, A., 1994. A simple and rapid preparation of infected plant tissue extracts for PCR amplification of virus, viroid and MLO nucleic acids. J. Virol. Methods 49, 295-304.

Liu, H.W., Goodwin, P.H., Kuske, C.R., 1994. Quantification of DNA from the aster yellows mycoplasmalike organism in aster leafhoppers (Macrosteles fascifrons Stal) by a competitive polymerase chain reaction. Syst. Appl. Microbiol. 17, 274-280.

Lorenz, K.H., Schneider, B., Ahrens, U., Seemuller, E., 1995. Detection of the apple proliferation and pear decline phytoplasmas by PCR amplification of ribosomal and nonribosomal DNA. Phytopathology 85, 771-776.

Marbot, S., Kummert, J., Salmon, M., Vendrame, M., Huwaert, A., Dutrecq, O., Lepoivre P., 2002. Development of RT-PCR tests for the routine detection of latent and ILAR viruses in fruit trees. Plant Protect. Sci. 38, 21-23.

Marcone, C., Gibb, K.S., Streten, C., Schneider, B., 2004. 'Candidatus Phytoplasma spartii', 'Candidatus Phytoplasma rhamni' and 'Candidatus Phytoplasma allocasuarinae', respectively associated with spartium witches'-broom, buckthorn witches'-broom and allocasuarina yellows diseases. Int. J. Syst. Evol. Microbiol. 54, 1025-1029.

Marinho, V.L.A., Kummert, J., Rufflard, G., Colinet, D., Lepoivre, P., 1998. Detection of apple stem grooving virus in dormant apple trees with crude extracts as templates for one-step RT-PCR. Plant Dis. 82, 785-790.

Marzachi, C., Bosco, D., 2005. Relative quantification of Chrysanthemum yellows (16SrI) phytoplasma in its plant and insect host using real-time polymerase chain reaction. Mol. Biotechnol. 30, 117-127.

Massart, S., Brostaux, Y., Barbarossa, L., Cesar, V., Cieslinska, M., Dutrecq, O., Fonseca, F., Guillem, R., Lavina, A., Olmos, A., Steyer, S., Wetzel, T., Kummert, J., Jijakli, M.H., 2008. Inter-laboratory evaluation of a duplex RT-PCR method using crude extracts for the simultaneous detection of prune dwarf virus and prunus necrotic ringspot virus. Eur. J. Plant Pathol. 122, 539-547. 
McGarvey, P., Kaper, J.M., 1991. A simple and rapid method for screening transgenic plants using the PCR. BioTechniques 11, 428-432.

Musetti, R., Favali, M.A., Pressacco, L., 2000. Histopathology and polyphenol content in plants infected by phytoplasmas. Cytobios 102,133-147.

Nakahara, K., Hataya, T., Uyeda, I., 1999. A simple, rapid method of nucleic acid extraction without tissue homogenization for detecting viroids by hybridization and RT-PCR. J. Virol. Methods 77, 47-58.

Palmano, S., 2001. A comparison of different phytoplasma DNA extraction methods using competitive PCR. Phytopathol. Medit. 40, 99-107.

Pandey, R.N., Adams, R.P., Flournoy, L.E., 1996. Inhibition of random amplified polymorphic DNAs (RAPDs) by plant polysaccharides. Plant Mol. Biol. Rep. 14, 17-22.

Ramakers, C., Ruijter, J.M., Lekanne Deprez, R.H., Moorman, A.F.M., 2003. Assumption-free analysis of quantitative real-time polymerase chain reaction (PCR) data. Neurosci. Lett. 339, 62-66.

Seemüller, E., Schneider, B., 2004. 'Candidatus Phytoplasma mali', 'Candidatus Phytoplasma pyri' and 'Candidatus Phytoplasma prunorum', the causal agents of apple proliferation, pear decline and European stone fruit yellows, respectively. Int. J. Syst. Evol. Microbiol. 54, 1217-1226.

Seemüller, E., Stolz, E., Kison, H., 1998. Persistence of European stone fruit yellow phytoplasma in aerial parts of Prunus taxa during the dormant season. J. Phytopathol. 146, 407-410.

Staub, U., Polivka, H., Gross, H.J., 1995. Two rapid microscale procedures for isolation of total RNA from leaves in polyphenols and polysaccharides: application for sensitive detection of grapevine viroids. J. Virol. Methods 52, 209-218.

Thomson, D., Dietzgen, R.G., 1995. Detection of DNA and RNA plant viruses by PCR and RT-PCR using a rapid virus release protocol without tissue homogenization. J. Virol. Methods 54, 5-95.

Torres, E., Bertolini, E., Cambra, M., Monton, C., Martin, M.P., 2005. Real-time PCR for simultaneous and quantitative detection of quarantine phytoplasmas from apple proliferation (16SrX) group. Mol. Cell. Probes 19, 334-340.

Wang, H., Qi, M., Cutler, A.J., 1993. A simple method of preparing plant samples for PCR. Nucleic Acids Res. 21, 4153-4154. 